\title{
内外リンパ混合による前庭半規管障害に関する実験的研究
}

\author{
中井 義明・小西 一夫・張 寛正 \\ 大橋 一博・杵谷 治彦
}

\section{Experimental Study on the Disorders of the Vestibule and Semicircular \\ Canals Due to Intermixture of Endolymph and Perilymph}

\author{
Yoshiaki Nakai, Kazuo Konishi, Kuan-cheng Chang, \\ Kazuhiro Ohashi and Haruhiko Masutani \\ (Osaka City University)
}

As a mechanism of the attack of Meniere's disease, membrane breake theory is proposed. The detailed observation of the effects induced by the mixture of endolymph with perilymph was considered to be useful for the diagnosis and treatment of vertiginous disease. We ruptured the saccular membrane of the guinea pig and observed the effects functionally and morphologically.

Functionally, horizontal-rotatory-mixing spontaneous nystagmus to the healthy side was observed, however, behavioral observation evealed no deviating tendency.

Morphologically, the degenerations of the sensori-epithelium, which were resemble to that induced by drug intoxication or accerating stimulus, were found in the maculae and the cristae ampullares. There were only slight disorders at the organ of Corti. Many vacuoles and vesicles and partial swelling were observed in the marginal cells, these findings were resemble to that of the dark cells and transitional cells of the cristae ampullares.

By these results, discussions were made on the relationship among the range of degeneration, endolymphatic flow and the attack of Meniere's disease.

\section{緒言}

メニェール病に於けるめまい発作発垷の機序として，内リンパ 水腫の生じた膜迷路破裂説が Lawrence ${ }^{1)}$, Schuknecht ${ }^{2) 3)}$ 以来提唱されて抢り，又，膜迷路破裂により生じたと思われる感音性 難聴の症例報告も認められる ${ }^{4) 5)}$. 膜迷路破裂に伴なら内外リンパ混合は内耳機能に影響を及ぼす

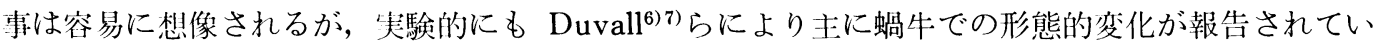
る.

我々は，内外リンパ混合の及ぼす影響を詳細に観察する事がメニエール病をはじめとするめまい 疾患の診断, ひいては治療の一助となるものと考光, 実験的にモルモットの球形囊膜を穿孔し, 機 
能的には自発眼振を，形態的には内耳，特に前庭半規管に及ぼす障害を観察し，ここに報告する.

\section{実 験 方 法}

実験動物には体重約 $400 \mathrm{~g}$ ，鼓膜所見及びプ ライエル反射正常のハートレイ系モルモット 30 匹を使用した. ペントバルビタール $30 \mathrm{mg} / \mathrm{Kg}$ 腹腔内注射による麻酔下に右側耳介後部に皮切 を加え，軟部組織を䟝離し側頭骨を露出する。 骨を削開し中耳腔を開放した後，千術用蹎微鏡 下に顔面神経管壁を一部削除し此空と鐙骨を 明視下に置き，正川空と鐙骨底に極めて近揬し た骨壁に約 $0.1 \mathrm{~mm}$ の小孔をあけ外リンパ流出 を確認する。その小孔り微細な彎曲した鈎を 球形囊に向けて刺入し穿孔する. 穿孔後は外科 用瞬間接着剂にて骨小孔表面を被覆し，更に中 耳腔も閉鎖する．セファロスポリン系抗生物質 を局所に撒布し軟部組織を縫合する．以上の操

\section{結}

手術施行したモルモット30匹中，手術失敗 2 例, 手術後死亡 5 例, 中耳炎, 内耳炎惹起した もの 7 例で，残り16例について観察を行った。

(1)機能的観察

球形囊膜穿孔翌日，怪度に頙部を患側に回旋 している例を認めたが 2 日後より軽減した。 1 発腿振は手術后 2 日めまで健側向き水平回旋混 合性眼振が認められた（Fig. 1)。 その頻度， 振幅とも経時的儿減少し，3日後より自発眼振 は消失した。

行動観察では, 手術後よりその行動量が極め て減少したが，翌日よりモルモットの殿部を刺 激すると左右に偏倚せずに前進する事が可能で あった。

(2)形態的変化

(1)耳石器の変化

耳石器には多少の大小不同を認めるものの

(Fig. 2), 特に有意の所見とは考えられなか った。一部に炎症性細胞と思われるものが耳石 に付着している像も観察された．（Fig. 3)
作は無菌的に施行する。術後は連日セファロス ポリン系抗生物質 $100 \mathrm{mg} / \mathrm{Kg}$ を筋注した.

1 週間後断頭, 側頭骨を採取し $2.5 \%$ グルタ ールアルデヒド， $2 \%$ オスミック酸にて 2 重固 定の後脱水, 一部は常法に従いエポキシ樹脂包 埋し, 光学顕微鏡及び日立H S-9, H-300型 透過電子顕微鏡にて観察した。一部は臨界点乾 燥後金蒸着を施し, J O E L - 50 A 型走查電子 顕微鏡にて観察した。

5 匹については平衡機能障害の有無钼察の為 行動観察を施行すると共に，術後 4 時間, 1 日，2 日， 3 日に眼振計にて自発眼振を記録し た。な打試料作製時中耳炎, 内耳炎などの感染 を生じていたものは観察の対象より除外した。

\section{果}

感覚上皮は II 型細胞に比較し I 型細胞の障害が 著明で（Fig. 4)，ミトコンドリヤや小胞体な どの細胞内小器官の膨化, 核の濃縮から空胞形 成，神経杯との離開，更には神経細胞の消失ま で種々の程度の変性:所見起星した（Fig．5)。 II 梨細胞にも小空胞の形成や核の濃縮が，又, 支抒細胞にも大きな空胞形成がみられたが，神 経終末や神経線維には障害は認められなかっ た. 神経細胞感覚毛は cuticula free areaより 生じた膨浲により囲みこまれたり, 感覚毛の融 合が散見された（Fig. 6).内リンパ腔には膜 で用まれ, 内に無構造物質を入れたものが散在 していた。

(ii) 半規管膨大部

感覍上皮の障害は耳石器头衡斑とほぼ同一の 様相を呈した。すなわち，I 型細胞に神経杯と の離開や大小の空胞形成, 神経細胞の消失など を認めた。 II 型細胞や支持細胞の変性所見や， 内リンパ腔の膜つ用まれた無靚造物質も平衡玟 と同様であった（Fig. 7 ). 


\section{球形襄膜穿孔後の自発眼振}

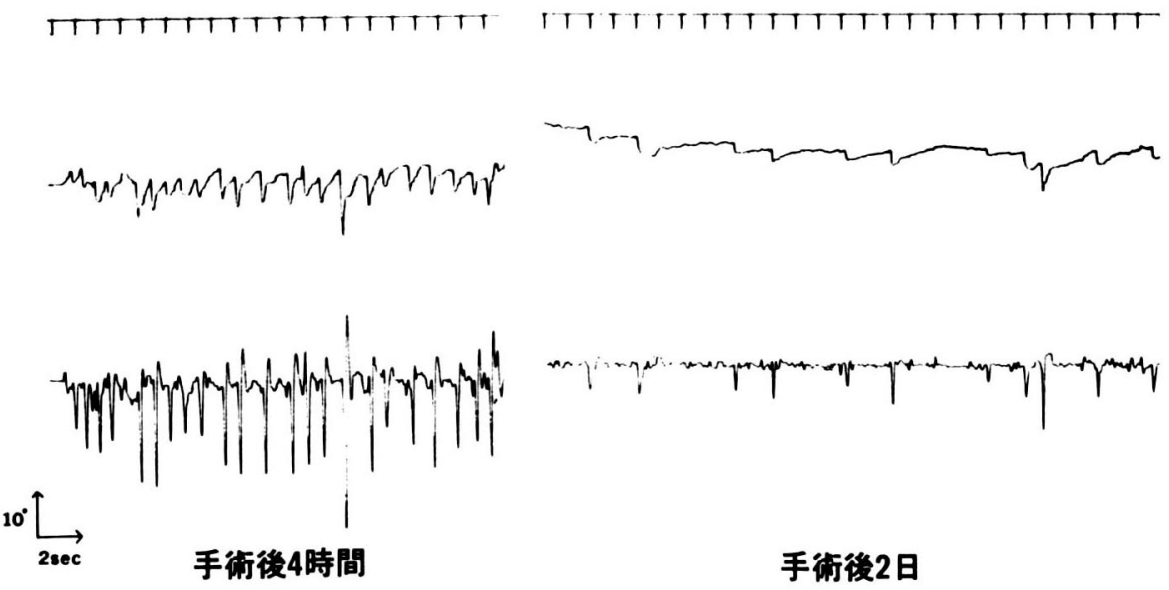

Fig. 1 : 球形囊膜穿孔後の自発眼振

健側向き水平回旋混合性自発眼振を認好る.

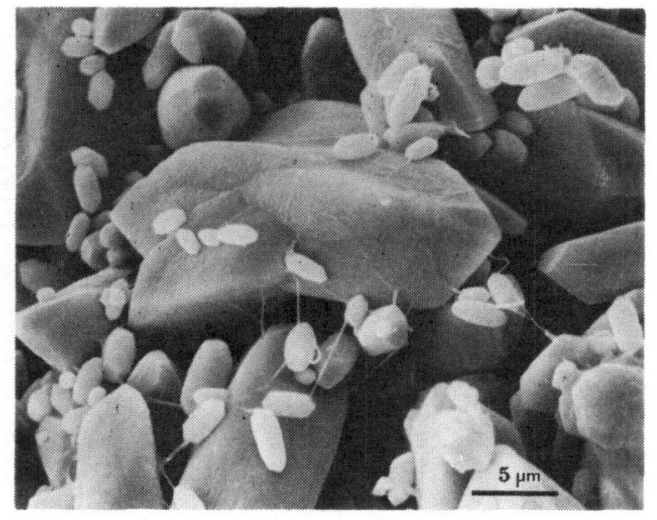

Fig. 2 : 球形囊膜穿孔旋 1 週間に於ける耳石 多少の大小不同を認るが有意の所見 とは思われない。

移行細胞表面は凹凸不整，膨隆及びその破裂 像, 分泌顆粒又は細胞破片と思われるものの付 着像が認められ (Fig. 8), 胞体内にも大小空 胞形成，核の濃縮を認めた。暗細胞にもほほ類 似の所見がみられた。なお，クプラについては 標本作成操作による変性もある為観察していな い.

(iii)蝸牛の変化

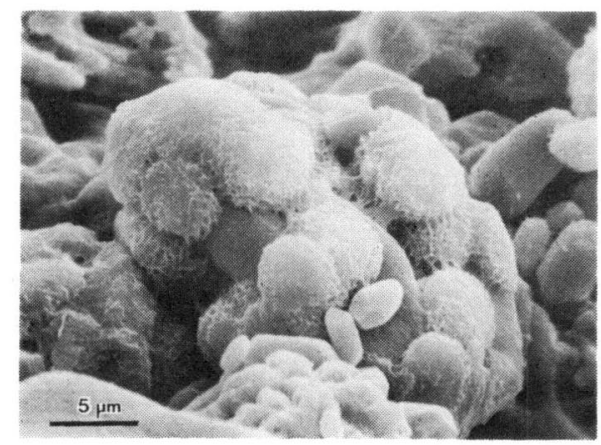

Fig. 3 : 同時期の耳石 耳石表面に炎症性細胞と思われるも のの付着像が稀に観察される.

蝸牛コルチ器は走查電顕的には各回転とも聴 毛の変形融合, 消失などの変化を認めなかっ た (Fig. 9). 透過電顕的にも变性所見は乏し く, 細胞膜下槽の乱れや小胞体の膨化などを示 すのみであった. 下方回転に於いてダイテルス 細胞が膨隆と有毛細胞体中央部まで包み込んで いる像も稀に観察された. 神経終末及び神経線 維には変化を認めなかった，しかし唯一例に於 いて中央階が虚脱し, 聴毛の消失, 著明な空胞 


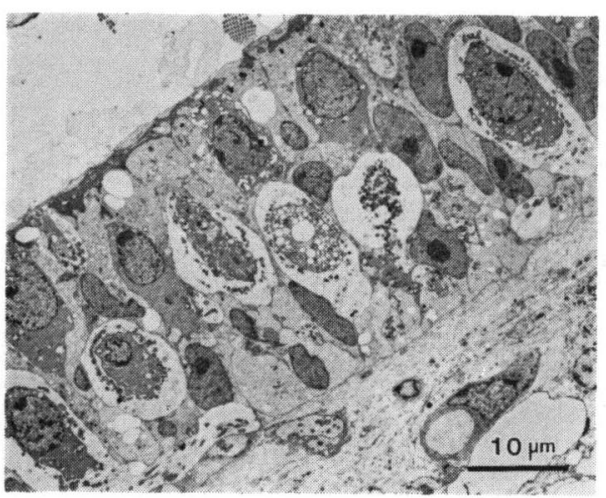

Fig. 4 : 球形囊感覚上皮の障害像 障害は I 型細胞に著明で， II 型細 胞, 支持細胞にも軽度の変性所見 を認める.内リン八腔内に膜で囲 まれた無構造物が散見される。

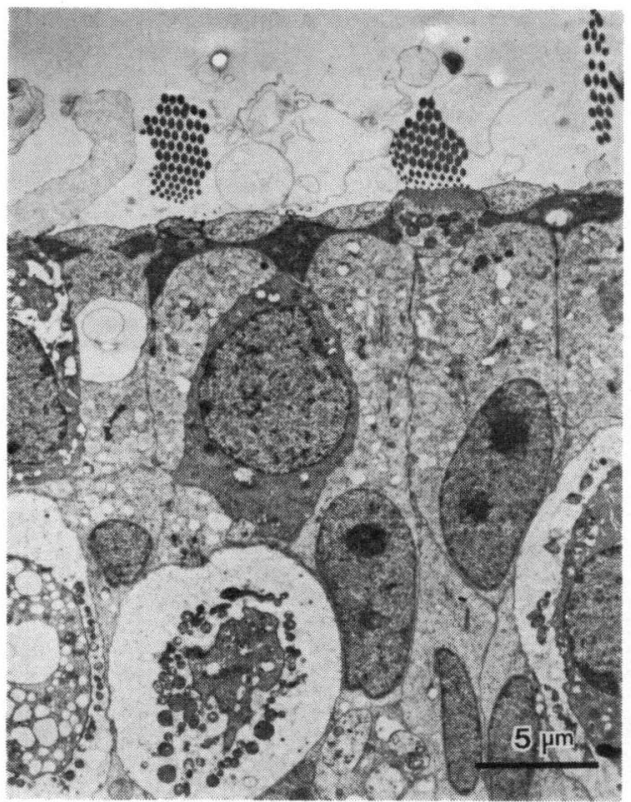

Fig. 5 : 同部㧪大像

I 型細胞にミトコンドリアや小胞 体などの膨化や神経杯との離開, 大小空胞形成などを認める。

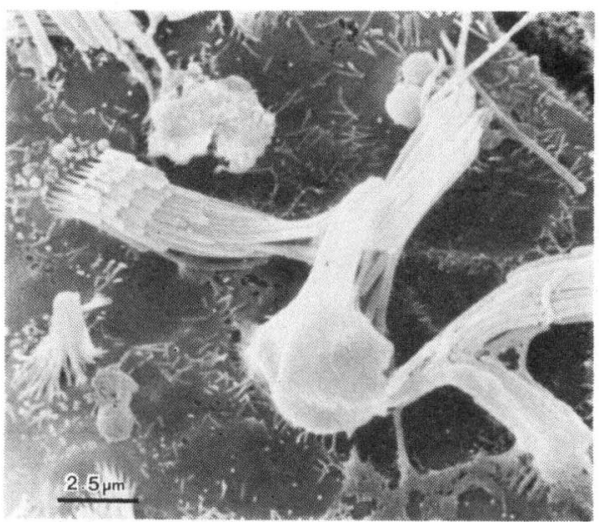

Fig. 6 : 球形囊感覚上皮感覚毛の融合.

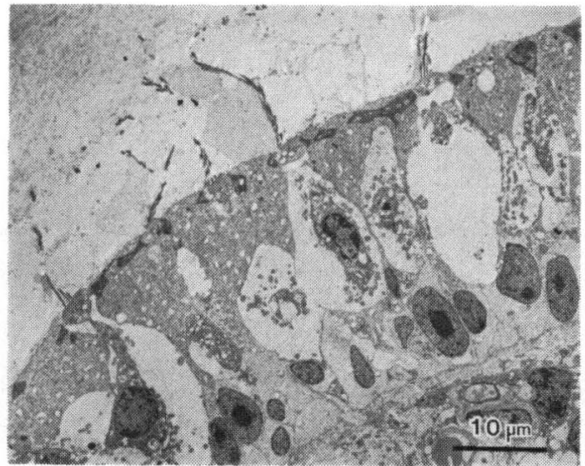

Fig. 7 : 半規管膨大部稜感覚上皮 平衡斑感覚上皮と同様 I 型細胞 に強い障害を羿みる。

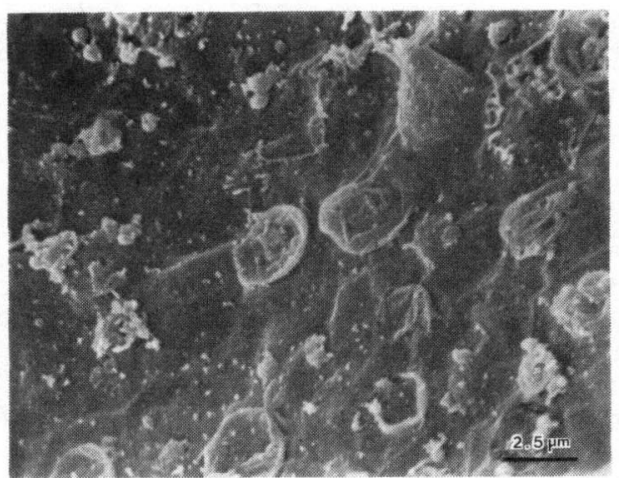

Fig. 8: 半規管膨大部移行上皮 表面の山凸不整，膨隆及び破裂 像, 分泌顆粒又は細胞破片と思 われるものの付着像を認める. 


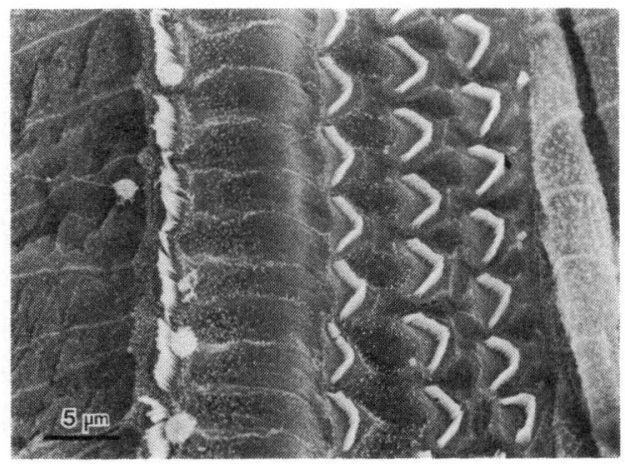

Fig. 9 : 蝸牛第 1 回転走査電顥像 蝸牛コルチ器は各回転とも殆ん ど障害を認めない。

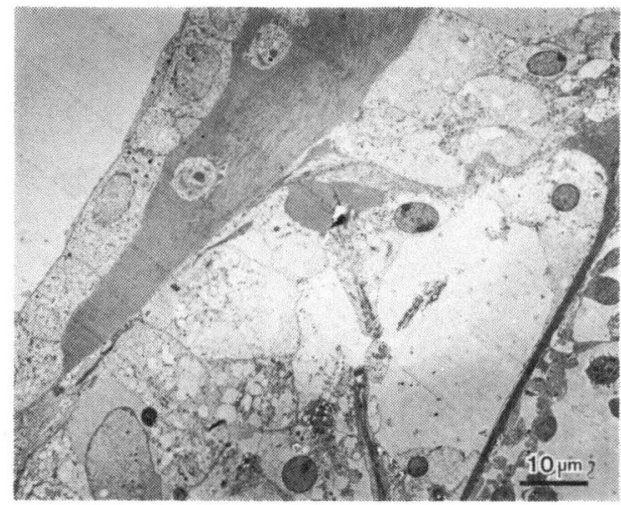

Fig. $10:$ 蝸牛第 2 回転透過電顕像 ただ 1 例において，中央階の虚脱， 有毛細胞の消失, ダイテルス細胞に よる置換など高度の変性を認めた。

考

メニエール病の基本病理として内リンパ水腫 が一般的に考学られている．1938年山川8) 以来 メニエール病患者の剖検例で数多くの内リンハ 水腫が報告されている，9)10)11)。しかし，内リ ンパ水腫のみでは反復するめまい発作を説明し 得,ずその発作発現の機序として，Lawrence ${ }^{1)}$, Schuknecht ${ }^{2)}{ }^{3)}$ 以来膜迷路破裂説が提唱されて いる. Schuknecht によれば，膜迷路破裂に伴 なら急激な内リンパ流動の変動がクプラや耳石 膜の偏位をもたらすと共に，内外リンパ混合に よる外リンパカリウムイオン濃度上昇が前庭神
形成，細胞膜の断裂，有毛細胞の消失，ダイ テルス細胞の膨隆及び置换などが観察された (Fig. 10)

血管条に於いてては，辺縁細胞，中間細胞の大 小の空胞形成，自由表面への軽度の膨隆及び破 裂像，細胞間隙の軽度増大を認めた (Fig.11). 基底細胞及び毛細血管には変化は殆んどみられ なかった。

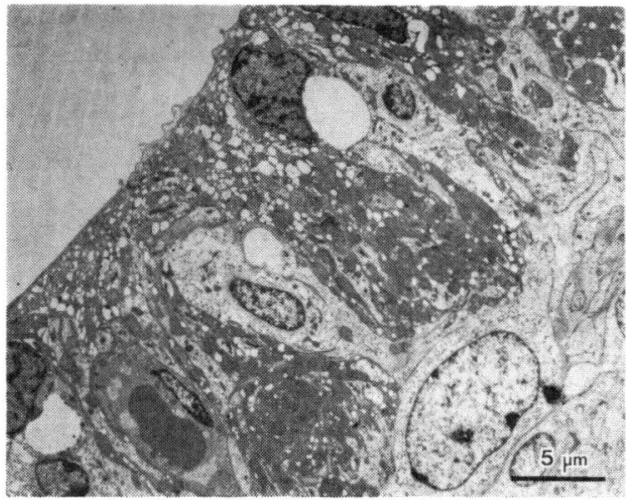

Fig. 11 ：血管条透過電影像 辺縁細胞，中間細胞に大小の空胞 形成，自由表面の膨隆及び破裂， 細胞間隚の軽度增大を認める。
察

経線維の一時的麻㽻を若起すると述べている。 しかし内外リンパ混合そのものが前庭あるいは 蝸牛の感覚細胞に形態的変化をもたらすとは言 及していない。

一方，Simmons はめまいを伴なら可逆性感 音性難聴の原因としてライスネル膜破裂及び正 円空又は卵円空膜破裂によると考元られる症例 を “The membrane break syndrome” として 報告している．すなわち，膜迷路破裂に伴なら 内外リンパのイオン組成の変動が広汎かつ重篤 な機能障害をもたらし，その組成の回復と共に 
機能も回復するが，穿孔部に於けるコルチ器の 器質的変化により小範囲の永久的聴力低下が残 存すると推察している. 又, Duvall677) らは䒠 験的にモルモットの蝸牛頂回転のライスネル膜 を穿孔させた結果, 穿孔部より上下 $1 \mathrm{~mm}$ 亿渡 る外有毛細胞の変性と穿孔部より頂回転側の血 管条及びらせん勒帯の萎縮などを報告し, 内外 リンパ混合が内耳に器質的変化をもたらす事を 示した.

今回我々は内外リンパ混合を目的として球形 虽膜を実験的に穿孔し，その絬果種々の形態的 変化を牛じる事を確認したが，Kaufman ${ }^{13)} ら$ はネコの球形囊膜穿孔後 4 時間にわたり螖牛電 位を測定した結果変化を認めないと報告してい る。五十嵐 ${ }^{14)}$ はリス猿の球形囊を選択的に破壊 した実験で組織学的に変化を認めないとしてい る.これらの報告は我々の今回の瑪絬果と相 反するものであるが，Kaufman らの実験は形 態的変化を惹起するにはあまりにも観察期間が 知かく, 五十嵐つ報告も例数が少なく, 光学顕 微鏡的観察にとどまっている.

我々の観察では, 球形囊膜穿孔一週間後に於 いて耳不器平衡斑感賞上皮に種 令の程度の変性: 所见を垫めた。こつ様式は種々の薬剂や加速度 刺激份荷と同様 ${ }^{15) 16)} \mathrm{I}$ 型紐胞に湿著であった。

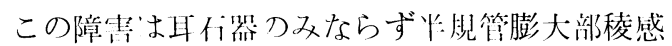
営上支にまで波及するが蝸牛コルチ器はあまり 障害されない。一」うでは，腤細胞，移行上皮， IfIl管条に比較的類似の障吉を垫めた.

内リンパ流動は蝸牛回転に沿って流動し内り ンパ霊で吸収されるという longitudinal flow ${ }^{17)}$ 説と蝸牛各部に於いて膜迷路を介して水分との 他の物質交換が行なわれるといら radial flow 説6) がある. 更に Juhn ${ }^{18)}$ らによれば内リン パは外らせん隆起, 外らせん溝, 内リンパ霊で 吸収され, longitudinal flow 及び radial flow 両者が生じていると考えている. 更に内耳は訃 統発生上，半規管，卵形愫上り成る pars superior と球形囊, 蝸牛より成る pars inferior に

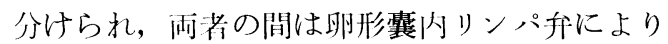

区切られ別々の内リンパ系が存在するといら考 え方がある19)。

我々の観察では pars inferior に属する球形 囊での障害が pars superior である半規管に 同程度に波及するのに対し，同じ pars inferior である螖牛にはあまり障害を及ぼさない。これ は球形囊から蝸牛に至るには内リンパ流動に逆 行する形になり影響が波及しにくく，又，卵形 囊内リンパ弁が pars inferior と pars superior 閒の仕切り弁としてあまり機能しなかった事が 推察される。唯一例に於いて認められた螖牛中 央階の虚脱，有毛細胞の消失など著明な変性:所 見は，穿孔部骨壁の閉鎖不全により内外リンパ 混合と中耳腔への流出が持続した為に生じたと 思われる. 一方, 膨大部移行細胞, 瞕細胞, 血 管条辺縁細胞に類似の変性所見を認めた小は， これらの細胞の機能が内リンパ商生又は吸収に

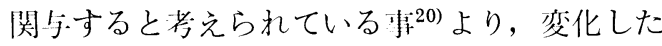
内リンパ組成を回復しょらと務めた絬果あらわ れた形態的表現であると思われる。

術后 2 日目まで認められた健側向き水平回旋 泥合性腿振は，球形囊機能の脱落症状ではな く，一側の前庭機能の低下によるものと考兄ら れる。鈴木 ${ }^{21222}$ らは中耳炎の内耳波及による眼 拢はその侵入部位により特徵们であり, 卵空 (耳们器) より侵入した場合は純回旋性とな り，一側の从耳全体に波及すると水平回旋混合 性になる小を臨林的に報告している，今回の成 績はこの知兄と一致し, 形態的にも一側迷路全. 体の障害による事が確認された.

我々は本実験に於いて, 球形囊に生じた内外 リンパ混合が機能的障害及び前庭半規管に形態 的変化をもたらす事を述べたが，実際に人体的 に於いて同程度の障害が惹起されるかは疑問で ある. 外科的手技を必要とする実験的研究には 骨削開時の 振動, 血液の 混入, 外リンパの流 出, 炎症又は感染など種々の人工産物の入る可 能性があり, 今问の観察対象よりこれらの危険 性のあるものを除外したが，観察例にも皆無と は断言できない。内リンパ水腫状態で生じた膜 
迷路破裂と正常迷路に生じた破裂では, 内外り ンパの混合状態, 内リンパの流出又は外リンパ の流入の程度が異なり両者を同レベルに論じる 事はできない.メニエール病に於いて今回の実 験結果の如き形態的変化が生じているとすれば, 当然現在まで報告されているはずであるし， 又, メニエール病の病型もおのずと異ったもの になると考号れる。すすなわち我々は, 内外り ンパ混合が内耳に形態的変化を及ぼすが，人体 内で自然に発生した膜迷路破裂では, その程度 はより軽度であると考えている。
今回の観察では穿孔部の膜の修復状態を観察 する事がでさなかった. Duvall6) らはライスネ 儿膜は穿孔後 2 週間以内に修復すると報告して おり，篠崎23)らは内リンパ水腫モルモットのラ イスネル膜に穿孔や out-pouching を認めてい る. 穿孔した膜の修復は穿孔の大ささにも関与 すると思われるが，今後修復様式や時期などに ついて観察を加えたい.更に，内リンパ水腫動 物に抢ける実験的膜迷路穿孔の形成，長期間に 渡る形態的変化の推移, 利尿剂やステロイドな ぞ治療効果の判定など今後検討を加えたい.

\section{ま と め}

モルモットの球形囊膜を実験的に穿孔し，内外リンパ混合のもたらす影響を機能的形態的に観察

し, 以下の結果を得た.

(1) 手術後 2 日まで健側向き水平回旋混合性眼振が惢められた.

(2) 1 週間後の形態的变化は耳不器平衡斑つみならず半規管膨大部に及んだ.

（3）感覚上皮の障害は I 型細胞に著明であるが，II 型細胞，支持細胞にも軽度の変性所見を示した.

(4) 蝸牛コルチ器にはほとんど変化を涩めなかった.

(5) 膨大部移行細胞，暗細胞，血管条辺縁細胞に類似の変性所見を認めた.

（6）ただ一例螖牛中央階の虚脱，コルチ器有毛細胞など高度の変性所見を認めた.

以上の結果より障害の進展と内リンパ流動, メニエール病発作との関連などについて考察を加え た.

本研究は厚生省特定疾患站这機能異常调查研究費による成果である.

\section{参考文 献}

1) Lawrence, M. and McCabe, B. F.: Inner ear mechanics and deafness: Special consideration of Ménière's syndrome• JAMA 171 : 1927-1932, 1956.

2) Schuknecht, H. F.: Ablation therapy for the relief of Ménière's disease. Laryngoscope 66 : 859-870, 1956.

3) Schuknecht, H. F. et al. : Further observation on the pathology of Ménière's disease. Ann. Otol. 71: 1039-1053, 1962.

4) Simmons, F. B.: Theory of Membrane Braks in Sudden Hearning Loss. Arch. Oto-RhinoLaryng. 88 : 41-48, 1968.

5) Goodhill, V.: Labyrinthine Membrane Ruptures in Sudden Sensorineural Hearing Loss. Proc. R. Soc. Med., 69 : 585-572, 1976.

6) Duvall, A. J. III, et al.: Ultrastructure of the organ of Corti following intermixing of cochlear fluids. Ann. Otol. 76 : 688-708, 1967.

7) Duvall, A. J.: Ultrastructure of the lateral cochear wall following intermixing of fluids. Ann. Otol. (St. Louis) 77: 317-331, 1968.

8) Yamakawa, K.: The pathology of a labyrinth with Ménière's disease. Jap. J. Otol. 44 : 23102312, 1938.

9) Altmann, F. and Kornfield, M.: Histological studies of Ménière's disease. Ann. Otol. 74 : 915-943, 1965. 
10) Lindsay, J. R., Kohut, R. I. and Sciarra, R. A.: Ménière's disease. Pathology and manifestations. Ann. Otol. 76 : 5-22, 1967.

11) Gussen, R. : Ménière's Disease : New temporal bone findings in two cases. Laryngoscope $\mathbf{8 1}$ : 1695-1707, 1971.

12) Simmons, F. B.: The double membrane break syndrome in sudden hearing loss. Laryngoscope 89 : 59-66, 1979.

13) Kaufman, R. S., Tonndorf, and Khannas, S. : Short-Term Changes in Cochlea Microphonics after Perfonation of the Saccule in the Cat. Laryngoscope 76 : 719-732, 1966.

14) Igarashi, M.: Histopathological findings after expeimental saccula destruction in the squirrel monkey. Laryngoscope 75 : 1048-1061, 1965.

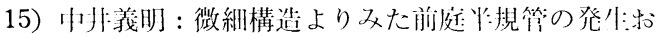
よびその焫態. Equilibrium Res. 39：169-173. 1980.

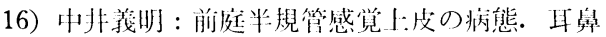

: 863-874, 1973.

17) Lundquist, P. G.: Aspects on endolymphatic sac morphology and function. Arch. Oto-RhinoLaryng. 212 : 231-240, 1976.

18) Juhn, S. K. and Rybak, L. P.: Labyrinthine barriers and cochlear homeostasis. Acta Otolaryngol. 91 : 529-534, 1981.

19）石井哲夫：メニエール病の基礎問題. 第 5 回耳鼻 咽喉科学譵習会テキスト。47-56, 1979

20) 原田康大 : 前庭特殊細胞の走査電顕的観察. 耳鼻 臨床 66 : 1293-1300, 1973.

21）鈴木淳一: Labyrinth ocular reflex. 神経研究の 進歩. 18：698-709, 1974 .

22）鉿木淳一：目で见る神経耳科学:のポイント。治療, 56 : 1669-1687, 1974.

23) Shinozaki, N. and Kimura, R. S.: Scanning electron microscopic observations on the distended Reissner's and Saccular membranes in the guinea pig. Acta Otolaryngol. 90: 370-384, 1980. 